\title{
Analisis Rasio Likuiditas, Solvabilitas dan Profitabilitas Dalam Menilai Kinerja Keuangan Pada PT. Goldman Costco Tbk Periode 2014-2018
}

\author{
Oktariansyah \\ Akuntansi, Fakultas Ekonomi Universitas PGRI Palembang \\ rianbro82@univpgri-palembang.ac.id
}

\begin{abstract}
ABSTRAK
Penelitian ini bertujuan untuk mengetahui kinerja keuangan PT. Goldman Costco Tbk yaitu dengan menganalisis rasio berupa rasio likuiditas, rasio solvabilitas dan rasio profitabilitas. Data yang diamati merupakan laporan keuangan PT. Goldman Costco Tbk berupa neraca dan laporan laba-rugi dari tahun 2014 sampai tahun 2018. Metode penelitian yang digunakan adalah metode kualitatif. Analisis data dan pembahasan menggunakan metode analisis horizontal dan analisis deskriptif dengan data kuantitatif. Alat analisis yang digunakan dalam penelitian ini adalah dengan menggunakan rasio likuiditas yang meliputi rasio lancar (current ratio) dan rasio cepat (quick ratio), rasio solvabilitas meliputi debt to assets ratio dan debt to equity ratio, rasio profitabilitas meliputi return on investment, net profit margin dan earning per share of common stock. Hasil pembahasan dapat diketahui bahwa tingkat rasio likuiditas PT. Goldman Costco Tbk selama tahun 2014-2018 yang diukur dengan current ratio dan quick ratio dinilai kurang baik, karena aktiva lancar lebih rendah dibandingkan kewajiban lancar yang harus dipenuhi. Tingkat rasio solvabilitas PT. Goldman Costco Tbk selama tahun 2014-2018 yang diukur dengan debt to assets ratio dan debt to equity ratio dinilai kurang baik, karena pendanaan perusahaan hampir separuhnya dibiayai oleh hutang yang berasal dari kreditor. Tingkat rasio profitabilitas PT. Goldman Costco Tbk selama tahun 2014-2018 yang diukur dengan net profit margin, return on investment dan earning per share of common stock dinilai kurang baik, karena manajemen perusahaan tidak efektif dalam pengelolaan operasi perusahaan.
\end{abstract}

Kata kunci: Kinerja keuangan, rasio likuiditas, rasio solvabilitas, rasio profitabilitas.

\begin{abstract}
This study aims to determine the financial performance of PT. Goldman Costco Tbk is by analyzing ratios in the form of liquidity ratios, solvency ratios and profitability ratios. Observed data are financial statements of PT. Goldman Costco Tbk in the form of balance sheet and income statement from 2014 to 2018. The research method used is a qualitative method. Data analysis and discussion using horizontal analysis methods and descriptive analysis with quantitative data. The analytical tool used in this study is to use liquidity ratios which include the current ratio and quick ratio, the solvency ratio includes the debt to assets ratio and debt to equity ratio, profitability ratios include return on investment, net profit margin and earnings per share of common stock. The results of the discussion can be seen that the level of liquidity ratio of PT. Goldman Costco Tbk during 2014-2018 as measured by the current ratio and quick ratio is considered not good, because current assets are lower than current liabilities that must be met. The level of solvency ratio of PT. Goldman Costco Tbk during 2014-2018 as measured by the debt to assets ratio and the debt to equity ratio was considered not good, because almost half of the company's funding was financed by debt originating from creditors. The level of profitability ratio of PT. Goldman Costco Tbk during 2014-2018 as measured by net profit margin, return on investment and earnings per share of common stock was considered not good, because the company's management was not effective in managing the company's operations.
\end{abstract}

Keywords: Financial performance, liquidity ratios, solvency ratios, profitability ratios. 


\section{A. PENDAHULUAN}

Pertumbuhan ekonomi di era globalisasi sekarang yang cukup pesat menuntut perusahaan untuk bekerja lebih efektif dan efisien dalam pengelolaannya. Perusahaan harus memiliki strategi untuk mencapai tujuan perusahaan dan agar tetap bertahan ditengah persaingan usaha yang begitu ketat. Selain itu, salah satu hal terpenting yang harus mampu dilakukan oleh perusahaan adalah mengatur posisi keuangannya dengan baik. Posisi keuangan tersebut digunakan sebagai tolak ukur kinerja keuangan perusahaan dan digunakan untuk mengetahui ada atau tidaknya kemajuan atau perkembangan di dalam perusahaan.

Salah satu media yang dapat digunakan untuk menilai kinerja keuangan adalah laporan keuangan. Laporan keuangan perusahaan diterbitkan tahunan, semesteran, triwulan bahkan harian yang dibuat dibagian akunting. Menurut Fahmi (2016:22), laporan keuangan merupakan suatu informasi yang menggambarkan kondisi suatu perusahaan, dimana selanjutnya itu akan menjadi suatu informasi yang menggambarkan tentang kinerja suatu perusahaan. Secara umum ada lima macam jenis laporan keuangan seperti : neraca, laporan laba rugi, laporan perubahan ekuitas, laporan catatan atas laporan keuangan, dan laporan arus kas.

Untuk mengetahui apakah laporan keuangan perusahaan dalam kondisi yang baik dapat dilakukan berbagai analisa, salah satunya analisis rasio keuangan. Analisis rasio keuangan membutuhkan laporan keuangan selama sedikitnya 2 (dua) tahun terakhir dari berjalannya perusahaan. Menurut Kasmir (2017:104), rasio keuangan merupakan kegiatan membandingkan angka-angka yang ada dalam laporan keuangan dengan cara membagi satu angka dengan angka lainnya. Rasio keuangan digunakan untuk mengevaluasi kondisi keuangan dan kinerja perusahaan. Hasil rasio keuangan ini akan terlihat kondisi kesehatan perusahaan yang bersangkutan juga dapat menilai kemampuan manajemen dalam memberdayakan sumber daya perusahaan secara efektif.

Analisis rasio keuangan dapat dilakukan dengan menggunakan beberapa rasio keuangan di antaranya yaitu ; (1) Rasio Likuiditas, (2) Rasio Solvabilitas, (3) Rasio Aktivitas, dan (4) Rasio Profitabilitas. Menurut Fahmi (2012:53), ada tiga rasio yang paling dominan yang dijadikan rujukan untuk melihat kondisi kinerja suatu perusahaan yaitu ; (1) Rasio Likuiditas, rasio ini mengukur kemampuan perusahaan dalam memenuhi kewajiban jangka pendeknya. Rasio ini penting karena kegagalan dalam membayar kewajiban dapat menyebabkan kebangkrutan perusahaan, (2) Rasio Solvabilitas, rasio ini menunjukkan bagaimana perusahaan mampu untuk mengelola utangnya dalam rangka memperoleh keuntungan dan juga mampu melunasi kembali utangnya, (3) Rasio Profitabilitas, rasio ini menunjukkan keberhasilan perusahaan dalam menghasilkan keuntungan. Ketiga rasio ini selalu menjadi perhatian terutama para investor karena secara dasar dianggap sudah mempresentatifkan analisis awal tentang kondisi suatu perusahaan, sedangkan rasio aktivitas digunakan untuk mengukur tingkat efisiensi pemanfaatan sumber daya perusahaan atau dengan kata lain rasio ini lebih besar manfaatnya hanya untuk manajemen perusahaan. 
Sehubungan dengan penilaian kinerja keuangan perusahaan PT. Goldman Costco Tbk menarik penulis untuk melakukan penelitian. PT. Goldman Costco Tbk adalah produsen minyak sawit mentah dan inti sawit Indonesia yang beroperasi di Sumatera Selatan, Indonesia. Operasi utama perusahaan meliputi penanaman kelapa sawit, produksi tandan buah segar dan pengolahan minyak sawit dan inti sawit untuk distribusi di Indonesia.

Tabel Laporan Laba Rugi Periode 2014-2018

(Dalam jutaan rupiah)

\begin{tabular}{|c|c|}
\hline Tahun & $\begin{array}{c}\text { Jumlah } \\
\text { Laba (Rugi) }\end{array}$ \\
\hline 2014 & 98.421 \\
\hline 2015 & 95.845 \\
\hline 2016 & 50.900 \\
\hline 2017 & 31.816 \\
\hline 2018 & $(1.547 .604)$ \\
\hline
\end{tabular}

Sumber : Laporan Keuangan PT. Goldman Costco Tbk (2014-2018)

Dari data tersebut secara umum bisa dilihat bahwa PT. Goldman Costco Tbk memiliki kinerja perusahaan yang menurun dari dalam perbandingan lima tahun yaitu pada 2014 hingga 2018. Namun bagaimana penilaian kinerja keuangan perusahaan dengan melihat analisis rasio keuangan apakah juga termasuk kategori kurang baik. Melalui analisis rasio keuangan kita bisa melihat secara spesifik dan lebih detail kinerja keuangan perusahaan sehingga bisa menjadi bahan pertimbangan bagi manajemen dalam pengambilan keputusan dan menetapkan kebijakan yang lebih tepat agar prestasi manajemen semakin baik daripada tahun-tahun sebelumnya dan bagi investor dalam pengambilan keputusan untuk berinvestasi di suatu perusahaan.

\section{B. KAJIAN TEORI}

1) Pengertian Laporan Keuangan

Menurut Kasmir (2017:7) dalam pengertian yang sederhana, laporan keuangan adalah laporan yang menunjukkan kondisi keuangan perusahaan pada saat ini atau dalam suatu periode tertentu. Sedangkan menurut Fahmi (2016:22), laporan keuangan merupakan suatu informasi yang menggambarkan kondisi suatu perusahaan, dimana selanjutnya itu akan menjadi suatu informasi yang menggambarkan tentang kinerja suatu perusahaan.

Menurut Sugiyono (2016:1), laporan keuangan pada perusahaan merupakan hasil akhir dari kegiatan akuntansi (siklus akuntansi) yang mencerminkan kondisi keuangan dan hasil operasi perusahaan. Oleh karena itu laporan keuangan dapat dipakai sebagai alat ukur berkomunikasi dengan pihak-pihak yang berkepentingan dengan data keuangan perusahaan.

Berdasarkan pengertian di atas dapat disimpulkan bahwa laporan keuangan adalah informasi yang didapat dari kegiatan akuntansi tentang kondisi keuangan dan kinerja perusahaan yang dapat dipakai sebagai alat ukur dan pengambilan kebijakan oleh pihak-pihak yang berkepentingan.

\section{2) Tujuan Laporan Keuangan}

Menurut Prastowo (2011:5), laporan keuangan disusun dengan tujuan untuk menyediakan informasi yang menyangkut posisi keuangan, kinerja, dan perubahan posisi keuangan suatu perusahaan yang bermanfaat bagi sejumlah besar pemakai dalam pengambilan keputusan ekonomi.

Menurut Kasmir (2017:11), tujuan pembuatan atau penyusunan laporan keuangan yaitu: 
a. Memberikan informasi tentang jenis dan jumlah aktiva (harta) yang dimiliki perusahaan pada saat ini;

b. Memberikan informasi tentang jenis dan jumlah kewajiban dan modal yang dimiliki perusahaan saat ini;

c. Memberikan informasi tentang jenis dan jumlah pendapatan yang diperoleh pada suatu periode tertentu;

d. Memberikan informasi tentang jumlah biaya dan jenis biaya yang dikeluarkan perusahaan dalam suatu periode tertentu;

e. Memberikan informasi tentang perubahan-perubahan yang terjadi terhadap aktiva, pasiva, dan modal perusahaan;

f. Memberikan informasi tentang kinerja manajemen perusahaan dalam suatu periode;

g. Informasi keuangan lainnya.

Jadi dapat disimpulkan bahwa tujuan laporan keuangan adalah memberikan informasi mengenai keuangan suatu perusahaan beserta perubahan-perubahan yang terjadi terhadap posisi keuangan tersebut yang selanjutnya informasi tersebut akan bermanfaat dalam pengambilan keputusan ekonomi.

\section{3) Pihak-pihak Pengguna Laporan Keuangan}

Menurut Harahap (2010:7), pengguna laporan keuangan meliputi pemilik perusahaan, manajemen perusahaan, investor, kreditur dan banker, pemerintah dan regulator, analis, akademis, dan pusat data bisnis. Sedangkan menurut Martani Dwi (2012:33), pengguna laporan keuangan meliputi investor, calon investor, pemberi pinjaman, karyawan, pemasok, kreditur lainnya, pelanggan, pemerintah, lembaga, dan masyarakat.
Menurut Kasmir (2017:25), pihakpihak pengguna laporan keuangan adalah:

a. Pemilik, guna melihat perkembangan dan kemajuan perusahaan serta dividen yang diperolehnya;

b. Manajemen, untuk menilai kinerjanya selama periode tertentu;

c. Kreditor, untuk menilai kelayakan perusahaan dalam memperoleh pinjaman dan kemampuan membayar pinjaman;

d. Pemerintah, untuk menilai kepatuhan perusahaan untuk membayar kewajibannya pada pemerintah;

e. Investor, untuk menilai prospek usaha tersebut ke depan, pakah mampu memberikan dividen dan nilai saham seperti yang diinginkan.

Dapat disimpulkan bahwa pengguna laporan keuangan adalah semua pihak-pihak yang berkepentingan untuk mengetahui informasi yang berkaitan dengan laporan keuangan.

\section{4) Jenis-jenis Laporan Keuangan}

Menurut Kasmir (2017:28) dalam praktiknya, secara umum ada lima macam jenis laporan keuangan yang biasa disusun, yaitu:

a. Neraca (balance sheet)

Neraca merupakan laporan yang menunjukan jumlah aktiva (harta), kewajiban (utang), dan modal perusahaan (ekuitas) perusahaan pada saat tertentu.

b. Laporan Laba Rugi (income statement)

Laporan laba rugi merupakan laporan yang menunjukkan kondisi uasaha dalam suatu periode tertentu yang tergambar dari jumlah pendapatannya yang 
diterima dan biaya yang telah dikeluarkan sehingga dapat diketahui apakah perusahaan dalam keadaan laba atau rugi.

c. Laporan Perubahan Modal Laporan perubahan modal menggambarkan jumlah modal yang dimiliki perusahaan saat ini serta sebab-sebab berubahnya modal.

d. Laporan Arus Kas

Laporan arus kas merupakan laporan yang menunjukkan arus kas masuk (pendapatan) dan arus kas keluar (baiaya-biaya).

e. Laporan Catatan Atas Laporan keuangan

Laporan catatan atas laporan keuangan merupakan laporan yang dibuat berkaitan dengan laporan keuangan yang disajikan. Laporan ini memberikan informasi tentang penjelasan yang dianggap perlu atas laporan keuangan yang ada sehingga menjadi jelas sebab penyebabnya.

\section{5) Manfaat Analisis Rasio Keuangan}

Menurut Fahmi (2012:47) adapun manfaat yang bisa diambil dengan dipergunakannya analisis rasio keuangan, yaitu:

a. Analisis Rasio keuangan sangat bermanfaat untuk dijadikan sebagai alat menilai kinerja dan prestasi perusahaan.

b. Analisis rasio keuangan sangat bermanfaat bagi pihak manajemen sebagai rujukan untuk membuat perencanaan

c. Analisis rasio keuangan dapat dijadikan sebagai alat untuk mengevaluasi kondisi suatu perusahaan dari perspektif keuangan.

d. Analisis rasio keuangan juga bermanfaat bagi para kreditor juga digunakan untuk memperkirakan potensi rasio yang akan dihadapi dikaitkan dengan adanya jaminan kelangsungan pembayaran bunga dan pengembalian pokok pinjaman.

e. Analisis rasio keuangan dapat dijadikan sebagai penilaian bagi pihak stakeholder organisasi.

\section{6) Bentuk-bentuk Keuangan}

\section{a. Rasio Likuiditas (Liquidity Ratio)}

Rasio likuiditas atau sering juga disebut dengan rasio modal kerja merupakan rasio yang digunakan untuk mengukur seberapa likuidnya suatu perusahaan. Penilaian dapat dilakukan untuk beberapa periode sehingga terlihat perkembangan likuiditas perusahaan dari waktu ke waktu.

Menurut Kasmir (2017:134), jenis-jenis rasio likuiditas yang dapat digunakan perusahaan untuk mengukur kemampuan, yaitu :

\section{Rasio Lancar (Current Ratio)}

Rasio lancar (current ratio) merupakan rasio untuk mengukur kemampuan perusahaan dalam membayar kewajiban jangka pendek atau utang yang segera jatuh tempo pada saat ditagih secara keseluruhan.

Rumus untuk mencari rasio lancar atau current ratio dapat digunakan sebagai berikut:

Current Ratio $\frac{\text { Aktiva Lancar (Current Assets) }}{\text { Utang Lancar (Current Liabilities) }}$

Rasio Cepat (Quick Ratio atau
$\begin{array}{llr}\text { Acid Test Ratio) } & & \\ \text { Rasio cepat } & \text { (quick ratio) } \\ \text { merupakan } & \text { rasio } & \text { yang } \\ \text { menunjukkan } & \text { kemampuan }\end{array}$


perusahaan dalam memenuhi atau membayar kewajiban atau utang lancar (utang jangka pendek) dengan aktiva lancar tanpa memperhitungkan nilai sediaan (inventory).

Rumus untuk mencari rasio cepat atau quick ratio dapat digunakan sebagai berikut :

Quick Ratio $\frac{\text { Current Assets - Inventory }}{\text { Current liabilities }}$

\section{b. Rasio Solvabilitas}

Rasio solvabilitas merupakan rasio yang digunakan untuk mengukur kemampuan perusahaan dalam membayar hutang jangka kewajiban jangka panjangnya apabila perusahaan dibubarkan atau dengan kata lain seberapa besar aktiva perusahaan dibiayai oleh hutang.

Menurut Kasmir (2017:155) , adapun jenis-jenis rasio solvabilitas yang sering digunakan oleh perusahaan, yaitu:

\section{Debt to Asset Ratio (Debt Ratio)}

Debt Ratio merupakan rasio utang yang digunakan untuk mengukur perbandingan antara total utang dengan total aktiva. Dengan kata lain, seberapa besar aktiva perusahaan dibiayai oleh utang atau seberapa besar utang perusahaan berpengaruh terhadap pengelolaan aktiva.

Rumus untuk mencari debt to asset ratio dapat digunakan sebagai berikut:

Debt to Assets Ratio $=\frac{\text { Total Debt }}{\text { Total Assets }}$

Debt to Equity Ratio

Debt to equity ratio merupakan rasio yang digunakan untukmenilai utang dengan ekuitas. Rasio ini dicari dengan cara membandingkan antara seluruh utang, termasuk utang lancar dengan seluruh ekuitas.

Rumus untuk mencari debt to equity ratio dapat digunakan sebagai berikut:

Debt to equity ratio $=\frac{\text { Total Utang }(\text { Debt })}{\text { Ekuitas }(\text { Equity })}$

\section{c. Rasio Profitabilitas}

Rasio profitabilitas merupakan rasio yang menggambarkan kemampuan perusahaan dalam menghasilkan keuntungan atau dengan kata lain rasio ini mengukur seberapa efektif manajemen suatu perusahaan dalam menghasilkan keuntungan.

Menurut Kasmir (2017:199), jenis-jenis Rasio profitabilitas yang dapat digunakan adalah :

\section{Margin Laba Bersih (Net Profit} Margin/NPM)

Margin laba bersih merupakan ukuran keuntungan dengan membandingkan antara laba setelah bunga dan pajak dibandingkan dengan penjualan. Rasio ini menunjukkan pendapatan bersih perusahaan atas penjualan.

Rumus untuk mencari net profit margin dapat digunakan sebagai berikut:

$$
\mathrm{NP}=\frac{\text { Earning After Interest and Tax }}{\text { Sales }}
$$

\section{Hasil Pengembalian Investasi (Return on investment/ROI)}

Hasil pengembalian investasi atau lebih dikenal dengan nama Return on Investment (ROI) atau return on total assets merupakan rasio yang menunjukkan hasil (return) atas jumlah aktiva yang 
digunakan dalam perusahaan. ROI juga merupakan suatu ukuran tentang efektivitas manajemen dalam mengelola investasinya.

Rumus untuk mencari Return on Investment dapat digunakan sebagai berikut:

$\mathrm{RO}=\frac{\text { Earning After Interest and Tax }}{\text { Total Assets }}$

\section{Laba Per Lembar Saham Biasa (Earning per Share of Common Stock/EPS)}

Rasio laba perlembar saham merupakan rasio untuk mengukur keberhasilan manajemen dalam mencapai keuntungan bagi pemegang saham.

Rumus untuk mencari Earning per Share of Common Stock dapat digunakan sebagai berikut:

$\mathrm{EPS}=\frac{\text { Laba saham biasa }}{\text { Saham biasa yang beredar }}$

Menurut Kasmir (2017:143), standar industri dari rasio keuangan adalah sebagai berikut :

Tabel Standar Industri Keuangan

\begin{tabular}{|c|c|}
\hline Rasio & Standar Industri \\
\hline Rasio Likuiditas & $\begin{array}{c}\text { Current Ratio : } 2 \text { kali } \\
\text { Quick Ratio : } 1,5 \mathrm{kali}\end{array}$ \\
\hline $\begin{array}{c}\text { Rasio } \\
\text { Solvabilitas } \\
\text { debt to assets ratio }: 35 \%\end{array}$ \\
\hline Rasio & $\begin{array}{c}\text { net profit margin }: 20 \% \\
\text { return on investment : } 30 \% \\
\text { Parning Per Share of } \\
\text { Common Stock }\end{array}$ \\
\hline
\end{tabular}

Sumber : Kasmir (2017)

\section{METODE PENELITIAN}

Menurut Sugiyono (2016:24), metode penelitian pada dasarnya merupakan cara ilmiah untuk mendapatkan data dengan tujuan dan kegunaan tertentu. Metode penelitian yang digunakan dalam penelitian ini adalah metode kualitatif.

Menurut Sugiyono (2016:38), metode kualitatif dapat diartikan sebagai metode penelitian yang berlandaskan pada filsafat postpositivisme/enterpretif, digunakan untuk meneliti pada kondisi obyek yang alamiah, (sebagai lawannya adalah eksperimen) dimana peneliti sebagai instrumen kunci, teknik pengumpulan data dilakukan secara trianggulasi (gabungan), analisis data bersifat induktif/kualitatif, dan hasil penelitian kualitatif lebih menekankan makna dari pada generalisasi.

\section{1) Populasi Dan Sampel \\ $>$ Populasi}

Menurut Sugiyono (2016:148), populasi adalah wilayah generalisasi yang terdiri atas: obyek/subyek yang mempunyai kuantitas dan karakteristik tertentu yang ditetapkan oleh peneliti untuk dipelajari dan kemudian ditarik kesimpulannya. Populasi dalam penelitian ini adalah laporan keuangan PT. Goldman Costco Tbk yang terdaftar di Bursa Efek Indonesia (BEl).

\section{$>$ Sampel}

Menurut Sugiyono (2016:149), sampel adalah bagian dari jumlah dan karakteristik yang dimiliki populasi tersebut. Bila populasi besar, dan peneliti tidak mungkin mempelajari semua yang ada pada populasi, misalnya karena keterbatasan dana, tenaga dan waktu, maka peneliti dapat menggunakan sampel yang diambil dari populasi itu. Apa yang dipelajari dari sampel itu, kesimpulannya akan dapat diberlakukan untuk populasi harus betul-betul representatif (mewakili). 
Sampel dalam penelitian ini adalah laporan keuangan yang berupa data neraca dan laporan laba rugi pada PT. Goldman Costco Tbk periode 2014-2018.

\section{2) Teknik Pengumpulan Data}

Menurut Sugiyono (2016:375), teknik pengumpulan data merupakan langkah yang paling utama dalam penelitian, karena tujuan utama dari penelitian adalah mendapatkan data.

Adapun teknik pengumpulan data yang dilakukan dalam penelitian ini adalah melalui sumber sekunder berupa dokumentasi yaitu data laporan keuangan periode 2014 sampai dengan 2018 dari PT. Goldman Costco Tbk yang terdaftar di BEl. Menurut Sugiyono (2016:376), sumber sekunder merupakan sumber yang tidak langsung memberikan data kepada pengumpul data, misalnya lewat orang lain atau lewat dokumen. Menurut Sugiyono (2016:396), dokumen merupakan catatan peristiwa yang sudah berlalu.

\section{3) Teknik Analisis Data}

Teknik analisis data yang digunakan adalah dengan menggunakan teknik analisis horizontal dan analisis deskriptif. Analisis Horizontal adalah analisis dengan mengadakan perbandingan laporan keuangan untuk beberapa saat sehingga akan diketahui perkembangannya (Munawir, 2010:36).

Analisis deskriptif dengan data kuantitatif, yaitu analisis data dengan menjelaskan secara rinci analisis rasio keuangan perusahaan dan kondisi keuangan perusahaan yang telah diteliti dari populasi dan sampel yang telah ditetapkan.

Dalam menganalisis penulis menggunakan rumus rasio likuiditas, solvabilitas, dan profitabilitas. Adapun rumus-rumus yang digunakan adalah:

\section{HASIL PENELITIAN Laporan Keuangan}

Laporan keuangan merupakan salah satu media yang dapat digunakan untuk menilai kinerja keuangan suatu perusahaan. Laporan keuangan menjadi salah satu informasi yang penting bagi pemakai laporan keuangan dalam rangka pengambilan kebijakan ekonomi termasuk investasi. Analisis laporan keuangan yang digunakan untuk menilai kinerja keuangan dan prestasi perusahaan sering menggunakan rasio atau indeks dimana analisis dan interprestasi dari macam-macam rasio dapat memberikan pandangan tentang kinerja keuangan dan prestasi perusahaan.

Jenis laporan yang digunakan dalam penelitian ini adalah sebagai berikut:

1. Neraca

Menurut Kasmir (2017:31), neraca merupakan laporan yang menunjukkan jumlah aktiva (harta), kewajiban (utang), dan modal perusahaan (ekuitas) perusahaan pada saat tertentu. Komponen yang terkandung dalam suatu aktiva dibagi menjadi 3 (tiga) yaitu : aktiva lancar, aktiva tetap, dan aktiva lainnya. Komponen kewajiban dibagi menjadi 2 (dua) jenis, yaitu : kewajiban lancar (utang jangka pendek) dan utang jangka panjang. Komponen modal terdiri dari 2 (dua) jenis yaitu : modal setor dan laba yang ditahan dan lainnya.

Berikut disajikan laporan keuangan PT. Goldman Costco Tbk tahun 2014-2018 yang terdiri atas laporan Neraca. 
Tabel Neraca

Per 31 Desember 2014-2015

(Dalam Jutaan Rupiah)

\begin{tabular}{|c|c|c|}
\hline Nama Akun & 2014 & 2015 \\
\hline \multicolumn{3}{|l|}{ ASET } \\
\hline \multicolumn{3}{|l|}{ ASET LANCAR } \\
\hline Kas dan setara kas & 231.533 & $\mathbf{1 7 5 . 5 3 3}$ \\
\hline Piutang usaha- Pihak ketiga & - & 2.615 \\
\hline \multicolumn{3}{|l|}{ Piutang lain-lain } \\
\hline Pihak berelasi & 1.245 & 438 \\
\hline Pihak ketiga & 2.377 & 2.671 \\
\hline Persediaan & 36.928 & 16.700 \\
\hline Uang muka & 64.925 & 82.967 \\
\hline Pajak dibayar di muka & 36.503 & 1.019 \\
\hline Biaya dibayar di muka & 1.633 & 1.411 \\
\hline Jumlah Aset Lancar & 374.881 & 283.354 \\
\hline \multicolumn{3}{|l|}{ ASET TIDAK LANCAR } \\
\hline Taksiran tagihan pajak penghasilan & $\mathbf{1 1 . 7 7 0}$ & 4.046 \\
\hline Piutang pihak berelasi & 131 & 131 \\
\hline Investasi pada asosiasi & 733.052 & 827.774 \\
\hline \multicolumn{3}{|l|}{ Tanaman perkebunan } \\
\hline Tanaman menghasilkan & 595.583 & 739.622 \\
\hline Tanaman belum menghasilkan & 603.479 & 494.229 \\
\hline Perkebunan plasma & 38.079 & 75.641 \\
\hline Aset tetap & 494.393 & 513.206 \\
\hline Goodwill & 263.102 & 263.102 \\
\hline Aset lain-lain bersih & 73.050 & - \\
\hline Jumlah Aset Tidak Lancar & 2.812.639 & 2.917.751 \\
\hline JUMLAH ASET & 3.187.520 & 3.201.105 \\
\hline \multicolumn{3}{|l|}{ LIABILITAS DAN EKUITAS } \\
\hline \multicolumn{3}{|l|}{ LIABILITAS JANGKA PENDEK } \\
\hline Hutang bank & 50.000 & 50.000 \\
\hline Hutang usaha- Pihak keriga & 56.039 & 93.732 \\
\hline Hutang lain-lain - Pihak ketiga & 1.859 & 2.124 \\
\hline Hutang pajak & 21.280 & 41.703 \\
\hline Beban masih harus dibayar & $\mathbf{1 0 . 0 7 3}$ & 12.861 \\
\hline Uang muka penjualan & 3.316 & 43.856 \\
\hline \multicolumn{3}{|l|}{ Bagian hutang jangka panjang } \\
\hline Jatuh tempo dalam satu tahun: & & \\
\hline Bank & 85.030 & 106.444 \\
\hline Lembaga keuangan & 16.981 & 23.914 \\
\hline Sewa pembiayaan & 3.284 & 4.671 \\
\hline Jumlah Liabilitas Jangka Pendek & 247.862 & 379.305 \\
\hline \multicolumn{3}{|l|}{ LIABILITAS JANGKA PANJANG } \\
\hline Liabilitas pajak tangguhan & 47.037 & 36.022 \\
\hline $\begin{array}{l}\text { Hutang jangka panjang- setelah } \\
\text { Dikurangi bagian jatuh tempo } \\
\text { dalam satu tahun : }\end{array}$ & & \\
\hline
\end{tabular}




\begin{tabular}{|l|r|r|}
\hline Bank & $\mathbf{9 9 5 . 9 4 9}$ & $\mathbf{9 9 9 . 8 0 4}$ \\
Lembaga keuangan & $\mathbf{2 8 9 . 6 7 4}$ & $\mathbf{2 7 2 . 4 9 7}$ \\
Sewa pembiayaan & $\mathbf{3 . 5 0 1}$ & $\mathbf{5 . 7 5 6}$ \\
\hline Liabilitas diestimasi atas imbalan kerja & $\mathbf{3 . 3 4 8}$ & $\mathbf{4 . 4 2 5}$ \\
\hline Jumlah Liabilitas Jangka Panjang & $\mathbf{1 . 3 3 9 . 5 0 9}$ & $\mathbf{1 . 3 1 8 . 5 0 4}$ \\
\hline Jumlah Liabilitas & $\mathbf{1 . 5 8 7 . 3 7 1}$ & $\mathbf{1 . 6 9 7 . 8 0 7}$ \\
\hline EKUITAS & & \\
\hline Jumlah Ekuitas & $\mathbf{1 . 6 0 0 . 1 4 9}$ & $\mathbf{1 . 5 0 3 . 2 9 6}$ \\
\hline JUMLAH LIABILITAS DAN & $\mathbf{3 . 1 8 7 . 5 2 0}$ & $\mathbf{3 . 2 0 1 . 1 0 5}$ \\
EKUITAS & & \\
\hline
\end{tabular}

Sumber: PT. Goldman Costco Tbk (2019)

Tabel Neraca

Per 31 Desember 2015-2016

(Dalam jutaan rupiah)

\begin{tabular}{|c|c|c|}
\hline \\
\hline Nama Akun & 2015 & 2016 \\
\hline \multicolumn{3}{|l|}{ ASET } \\
\hline \multicolumn{3}{|l|}{ ASET LANCAR } \\
\hline Kas dan setara kas & 175.533 & $\mathbf{1 0 2 . 1 2 5}$ \\
\hline Piutang usaha- Pihak ketiga & 2.615 & 1.274 \\
\hline \multicolumn{3}{|l|}{ Piutang lain-lain } \\
\hline Pihak berelasi & 438 & 755 \\
\hline Pihak ketiga & 2.671 & 2.196 \\
\hline Persediaan & 16.700 & 15.866 \\
\hline Uang muka & 82.967 & 81.236 \\
\hline Pajak dibayar di muka & 1.019 & $\mathbf{1 . 5 0 5}$ \\
\hline Biaya dibayar di muka & 1.411 & 1.215 \\
\hline Jumlah Aset Lancar & 283.354 & 206.172 \\
\hline \multicolumn{3}{|l|}{ ASET TIDAK LANCAR } \\
\hline Taksiran tagihan pajak penghasilan & 4.046 & 3.096 \\
\hline Piutang pihak berelasi & 131 & 131 \\
\hline Investasi pada asosiasi & 827.774 & 954.099 \\
\hline Tanaman perkebunan & & \\
\hline Tanaman menghasilkan & 739.622 & 924.727 \\
\hline Tanaman belum menghasilkan & 494.229 & 284.808 \\
\hline Perkebunan plasma & 75.641 & 94.466 \\
\hline Aset tetap & 513.206 & 502.043 \\
\hline Goodwill & 263.102 & 263.102 \\
\hline Aset lain-lain bersih & - & - \\
\hline Jumlah Aset Tidak Lancar & 2.917.751 & 3.026.472 \\
\hline JUMLAH ASET & 3.201 .105 & 3.232 .644 \\
\hline \multicolumn{3}{|l|}{ LIABILITAS DAN EKUITAS } \\
\hline \multicolumn{3}{|l|}{ LIABILITAS JANGKA PENDEK } \\
\hline Hutang bank & 50.000 & - \\
\hline Hutang usaha- Pihak keriga & 93.732 & 81.167 \\
\hline Hutang lain-lain - Pihak ketiga & 2.124 & 2.150 \\
\hline Hutang pajak & 41.703 & 54.533 \\
\hline
\end{tabular}




\begin{tabular}{|c|c|c|}
\hline Beban masih harus dibayar & 12.861 & 16.311 \\
\hline Uang muka penjualan & 43.856 & 944 \\
\hline \multicolumn{3}{|l|}{ Bagian hutang jangka panjang } \\
\hline Bank & 106.444 & 50.347 \\
\hline Lembaga keuangan & 23.914 & 24.459 \\
\hline Sewa pembiayaan & 4.671 & 3.908 \\
\hline Jumlah Liabilitas Jangka Pendek & 379.305 & 233.819 \\
\hline \multicolumn{3}{|l|}{ LIABILITAS JANGKA PANJANG } \\
\hline Liabilitas pajak tangguhan & 36.022 & 6.925 \\
\hline \multicolumn{3}{|l|}{$\begin{array}{l}\text { Hutang jangka panjang- setelah } \\
\text { Dikurangi bagian jatuh tempo } \\
\text { dalam satu tahun: }\end{array}$} \\
\hline Bank & 999.804 & $\mathbf{1 . 1 7 7 . 8 3 0}$ \\
\hline Lembaga keuangan & 272.497 & 249.738 \\
\hline Sewa pembiayaan & 5.756 & 1.866 \\
\hline Liabilitas diestimasi atas imbalan kerja & 4.425 & 12.947 \\
\hline Jumlah Liabilitas Jangka Panjang & 1.318.504 & 1.449 .306 \\
\hline Jumlah Liabilitas & $\mathbf{1 . 6 9 7 . 8 0 7}$ & 1.683 .125 \\
\hline \multicolumn{3}{|l|}{ EKUITAS } \\
\hline Jumlah Ekuitas & 1.503 .296 & $\mathbf{1 . 5 4 9 . 5 1 9}$ \\
\hline $\begin{array}{lll}\text { JUMLAH } & \text { LIABILITAS } & \text { DAN } \\
\text { EKUITAS } & & \end{array}$ & 3.201 .105 & 3.232 .644 \\
\hline
\end{tabular}

Sumber : PT. Goldman Costco Tbk (2019)

Tabel Neraca

Per 31 Desember 2016-2017

(Dalam jutaan rupiah)

\begin{tabular}{|l|r|r|}
\hline \multicolumn{1}{|c|}{ Nama Akun } & \multicolumn{1}{|c|}{$\mathbf{2 0 1 6}$} & \multicolumn{1}{c|}{2017} \\
\hline ASET & & \\
\hline ASET LANCAR & $\mathbf{1 0 2 . 1 2 5}$ & $\mathbf{1 1 3 . 0 6 2}$ \\
\hline Kas dan setara kas & $\mathbf{1 . 2 7 4}$ & $\mathbf{9 6 6}$ \\
\hline Piutang usaha- Pihak ketiga & $\mathbf{7 5 5}$ & $\mathbf{1 . 0 5 5}$ \\
\hline Piutang lain-lain & $\mathbf{2 . 1 9 6}$ & $\mathbf{5 . 1 1 0}$ \\
\hline Pihak berelasi & $\mathbf{1 5 . 8 6 6}$ & $\mathbf{5 0 . 0 8 9}$ \\
\hline Pihak ketiga & $\mathbf{8 1 . 2 3 6}$ & $\mathbf{8 1 . 3 4 6}$ \\
\hline Persediaan & $\mathbf{1 . 5 0 5}$ & $\mathbf{4 . 0 5 4}$ \\
\hline Uang muka & $\mathbf{1 . 2 1 5}$ & $\mathbf{1 . 7 0 2}$ \\
\hline Pajak dibayar di muka & $\mathbf{2 0 6 . 1 7 2}$ & $\mathbf{2 5 7 . 3 8 4}$ \\
\hline Biaya dibayar di muka & & $\mathbf{1 1 . 6 8 8}$ \\
\hline Jumlah Aset Lancar & $\mathbf{3 . 0 9 6}$ & $\mathbf{1 3 1}$ \\
\hline ASET TIDAK LANCAR & $\mathbf{1 3 1}$ & $\mathbf{1 . 0 4 9 . 9 1 4}$ \\
\hline Taksiran tagihan pajak penghasilan & $\mathbf{9 5 4 . 0 9 9}$ & \\
\hline Piutang pihak berelasi & & $\mathbf{2 . 1 0 8 . 6 5 0}$ \\
\hline Investasi pada asosiasi & $\mathbf{9 2 4 . 7 2 7}$ & $\mathbf{2 7 4 . 7 7 5}$ \\
\hline Tanaman perkebunan & $\mathbf{2 8 4 . 8 0 8}$ & \\
Tanaman menghasilkan & & \\
Tanaman belum menghasilkan & & \\
\hline
\end{tabular}




\begin{tabular}{|c|c|c|}
\hline Perkebunan plasma & 94.466 & 133.636 \\
\hline Aset tetap & 502.043 & 864.794 \\
\hline Goodwill & 263.102 & 263.102 \\
\hline Aset lain-lain bersih & - & 2 \\
\hline Jumlah Aset Tidak Lancar & 3.026.472 & 4.706 .692 \\
\hline JUMLAH ASET & 3.232 .644 & 4.964 .076 \\
\hline \multicolumn{3}{|l|}{ LIABILITAS DAN EKUITAS } \\
\hline \multicolumn{3}{|l|}{ LIABILITAS JANGKA PENDEK } \\
\hline Hutang bank & - & - \\
\hline Hutang usaha- Pihak keriga & 81.167 & 35.738 \\
\hline Hutang lain-lain - Pihak ketiga & 2.150 & 3.111 \\
\hline Hutang pajak & 54.533 & 32.728 \\
\hline Beban masih harus dibayar & 16.311 & 22.481 \\
\hline Uang muka penjualan & 944 & - \\
\hline \multicolumn{3}{|l|}{$\begin{array}{l}\text { Bagian hutang jangka panjang } \\
\text { Jatuh tempo dalam satu tahun: }\end{array}$} \\
\hline Bank & 50.347 & 75.536 \\
\hline Lembaga keuangan & 24.459 & 30.619 \\
\hline Sewa pembiayaan & 3.908 & 4.263 \\
\hline Jumlah Liabilitas Jangka Pendek & 233.819 & 204.503 \\
\hline \multicolumn{3}{|l|}{ LIABILITAS JANGKA PANJANG } \\
\hline Liabilitas pajak tangguhan & 6.925 & 360.172 \\
\hline \multicolumn{3}{|l|}{$\begin{array}{l}\text { Hutang jangka panjang- setelah } \\
\text { Dikurangi bagian jatuh tempo } \\
\text { dalam satu tahun: }\end{array}$} \\
\hline Bank & $\mathbf{1 . 1 7 7 . 8 3 0}$ & 1.479 .706 \\
\hline Lembaga keuangan & 249.738 & 220.625 \\
\hline Sewa pembiayaan & 1.866 & 5.439 \\
\hline Liabilitas diestimasi atas imbalan kerja & 12.947 & 23.561 \\
\hline Jumlah Liabilitas Jangka Panjang & 1.449 .306 & 2.089.557 \\
\hline Jumlah Liabilitas & 1.683 .125 & 2.294 .060 \\
\hline \multicolumn{3}{|l|}{ EKUITAS } \\
\hline Jumlah Ekuitas & 1.549.519 & 2.670 .016 \\
\hline $\begin{array}{lll}\text { JUMLAH } & \text { LIABILITAS } & \text { DAN } \\
\text { EKUITAS } & \end{array}$ & 3.232.644 & 4.964.076 \\
\hline
\end{tabular}

Sumber : PT. Goldman Costco Tbk (2019)

Tabel Neraca

Per 31 Desember 2017-2018

(Dalam jutaan rupiah)

\begin{tabular}{|l|r|r|}
\hline \multicolumn{1}{|c|}{ Nama Akun } & \multicolumn{1}{|c|}{$\mathbf{2 0 1 7}$} & \multicolumn{1}{c|}{2018} \\
\hline ASET & & \\
\hline ASET LANCAR & & $\mathbf{1 1 3 . 0 6 2}$ \\
\hline Kas dan setara kas & $\mathbf{9 6 6}$ & $\mathbf{3 . 3 6 5}$ \\
\hline Piutang usaha- Pihak ketiga & & - \\
\hline Piutang lain-lain & $\mathbf{1 . 0 5 5}$ & $\mathbf{2 . 6 0 9}$ \\
\hline Pihak berelasi & $\mathbf{5 . 1 1 0}$ & $\mathbf{2 0 5}$ \\
\hline Pihak ketiga & & \\
\hline
\end{tabular}




\begin{tabular}{|c|c|c|}
\hline Persediaan & $\mathbf{5 0 . 0 8 9}$ & $\mathbf{1 3 . 7 2 6}$ \\
\hline Uang muka & 81.346 & 80.726 \\
\hline Pajak dibayar di muka & 4.054 & 6 \\
\hline Biaya dibayar di muka & 1.702 & 1.001 \\
\hline Jumlah Aset Lancar & 257.384 & $\mathbf{1 4 8 . 3 8 7}$ \\
\hline \multicolumn{3}{|l|}{ ASET TIDAK LANCAR } \\
\hline Taksiran tagihan pajak penghasilan & 11.688 & 9.883 \\
\hline Piutang pihak berelasi & 131 & 131 \\
\hline Investasi pada asosiasi & 1.049.914 & - \\
\hline Tanaman perkebunan & & \\
\hline Tanaman menghasilkan & 2.108.650 & 1.963 .563 \\
\hline Tanaman belum menghasilkan & 274.775 & 194.841 \\
\hline Perkebunan plasma & 133.636 & 218.939 \\
\hline Aset tetap & 864.794 & 879.980 \\
\hline Goodwill & 263.102 & 131.250 \\
\hline Aset lain-lain bersih & 2 & 49 \\
\hline Jumlah Aset Tidak Lancar & 4.706 .692 & 3.398 .636 \\
\hline JUMLAH ASET & 4.964.076 & 3.547 .023 \\
\hline \multicolumn{3}{|l|}{ LIABILITAS DAN EKUITAS } \\
\hline \multicolumn{3}{|l|}{ LIABILITAS JANGKA PENDEK } \\
\hline Hutang bank & - & 45.000 \\
\hline Hutang usaha- Pihak keriga & 35.738 & 56.488 \\
\hline Hutang lain-lain - Pihak ketiga & 3.111 & 7.816 \\
\hline Hutang pajak & 32.728 & $\mathbf{1 1 . 5 2 4}$ \\
\hline Beban masih harus dibayar & 22.481 & 32.043 \\
\hline Uang muka penjualan & - & 30.000 \\
\hline \multicolumn{3}{|l|}{ Bagian hutang jangka panjang } \\
\hline Jatuh tempo dalam satu tahun: & & \\
\hline Bank & 75.536 & 61.921 \\
\hline Lembaga keuangan & 30.619 & 40.977 \\
\hline Sewa pembiayaan & 4.263 & 2.404 \\
\hline Jumlah Liabilitas Jangka Pendek & 204.503 & 288.173 \\
\hline \multicolumn{3}{|l|}{ LIABILITAS JANGKA PANJANG } \\
\hline Liabilitas pajak tangguhan & 360.172 & 309.766 \\
\hline \multicolumn{3}{|l|}{$\begin{array}{l}\text { Hutang jangka panjang- setelah } \\
\text { Dikurangi bagian jatuh tempo } \\
\text { dalam satu tahun : }\end{array}$} \\
\hline Bank & 1.479 .706 & 1.594.354 \\
\hline Lembaga keuangan & 220.625 & 180.007 \\
\hline Sewa pembiayaan & 5.439 & 1.775 \\
\hline Liabilitas diestimasi atas imbalan kerja & 23.561 & 28.441 \\
\hline Jumlah Liabilitas Jangka Panjang & 2.089.557 & 2.114 .343 \\
\hline Jumlah Liabilitas & 2.294 .060 & 2.402 .516 \\
\hline \multicolumn{3}{|l|}{ EKUITAS } \\
\hline Jumlah Ekuitas & 2.670 .016 & 1.144 .507 \\
\hline $\begin{array}{lll}\text { JUMLAH } & \text { LIABILITAS } & \text { DAN } \\
\text { EKUITAS } & & \\
\end{array}$ & 4.964.076 & 3.547 .023 \\
\hline
\end{tabular}

Sumber : PT. Goldman Costco Tbk (2019) 
2. Laporan laba rugi

Menurut Kasmir (2017:45), laporan laba rugi merupakan laporan yang menunjukkan kondisi usaha dalam suatu periode tertentu yang tergambar dari jumlah pendapatan yang diterima dan biaya yang telah dikeluarkan sehingga dapat diketahui apakah perusahaan dalam keadaan laba atau rugi. Komponen pendapatan yang dilaporkan dalam laporan laba rugi terdiri dari 2 (dua) jenis, yaitu : Pendapatan atau penghasilan yang diperoleh dari usaha pokok (usaha utama) perusahaan dan pendapatan atau penghasilan yang diperoleh dari luar usaha pokok (usaha sampingan perusahaan). Komponen pengeluaran atau biaya-biaya terdiri dari 2 (dua) jenis, yaitu : pengeluaran atau biaya yang dibebankan dari usaha pokok (usaha utama) perusahaan dan pengeluaran atau biaya yang dibebankan dari luar usaha pokok (usaha sampingan) perusahaan.

Berikut disajikan laporan keuangan PT. Goldman Costco Tbk tahun 2014-2018 yang terdiri atas laporan Laba rugi.

Tabel Laporan Laba-Rugi

Per 31 Desember 2014-2018 (Dalam Jutaan Rupiah)

\begin{tabular}{|l|r|r|r|r|r|}
\hline \multicolumn{1}{|c|}{ Nama Akun } & \multicolumn{1}{c|}{$\mathbf{2 0 1 4}$} & \multicolumn{1}{c|}{$\mathbf{2 0 1 5}$} & $\mathbf{2 0 1 6}$ & $\mathbf{2 0 1 7}$ & \multicolumn{1}{c|}{$\mathbf{2 0 1 8}$} \\
\hline PENJUALAN BERSIH & 405.328 & 427.623 & 462.840 & 491.605 & 544.884 \\
\hline BEBAN POKOK PENJUALAN & $(248.032)$ & $(340.139)$ & $(324.962)$ & $(381.189)$ & $(687.781)$ \\
\hline LABA BRUTO & 157.296 & 87.484 & 137.878 & 110.416 & $(142.897)$ \\
\hline $\begin{array}{l}\text { LABA (RUGI) SEBELUM } \\
\text { TAKSIRAN PENGHASILAN } \\
\text { (BEBAN) PAJAK }\end{array}$ & 115.209 & $(88.540)$ & 47.712 & $(55.116)$ & $(1.593 .545)$ \\
\hline TAKSIRAN BEBAN PAJAK & 16.788 & 7.305 & 3.188 & 23.300 & 45.941 \\
\hline $\begin{array}{l}\text { LABA (RUGI) TAHUN } \\
\text { BERJALAN }\end{array}$ & 98.421 & 95.845 & 50.900 & $(31.816)$ & $(1.547 .604)$ \\
\hline $\begin{array}{l}\text { JUMLAH LABA (RUGI) } \\
\text { KOMPREHENSIF TAHUN } \\
\text { BERJALAN }\end{array}$ & 98.421 & 95.845 & 49.624 & 1.120 .508 & $(1.548 .637)$ \\
\hline $\begin{array}{l}\text { LABA (RUGI) } \\
\text { PER SAHAM DASAR }\end{array}$ & 16.17 & 15.34 & 8.78 & 5.12 & 255.99 \\
\hline
\end{tabular}

Sumber: PT. Goldman Costco Tbk

\section{Kinerja Keuangan}

Kinerja keuangan merupakan suatu hasil atau prestasi yang telah dicapai oleh perusahaan dan menjadi tolak ukur dari keberhasilan perusahaaan dalam menghasilkan laba. Suatu perusahaan dapat dikatakan berhasil apabila telah mencapai standar dan tujuan yang telah ditetapkan.

Berikut perhitungan rasio-rasio selama 5 periode (2014-2018) yang dapat menjadi tolak ukur dalam menilai kinerja keuangan :

1. Rasio Likuiditas

a. Current Ratio

Current ratio menunjukkan seberapa aktiva lancar yang tersedia untuk menutupi kewajiban jangka pendek yang akan segera jatuh tempo. Current ratio dikatakan pula sebagai bentuk untuk mengukur tingkat keamanan (margin of safety) suatu perusahaaan. 
Current Ratio $\frac{\text { Aktiva Lancar (Current Assets) }}{\text { Utang Lancar (Current Liabilities) }}$

$2014=\underline{374.881}=1,51 \mathrm{kal}$ 247.862

Pada tahun 2014 current ratio yang di peroleh sebesar 1,51 kali yang artinya aktiva lancar pada tahun 2014 yaitu Rp. $\quad 374.881$ belum dapat menyediakan dana untuk menutupi kewajiban jangka pendek yaitu sebesar Rp. 247.862. walaupun pada kenyataannya nilai aktiva lebih besar di bandingkan dengan nilai utang lancarnya, tetapi hasil current ratio yang di dapat belum mencapai standar industri current ratio yang telah ditetapkan yaitu sebesar 2 kali.

$2015=\frac{283.354}{379.305}=0,75$ kali

Pada tahun 2015 current ratio yang di peroleh sebesar 0,75 kali yang artinya aktiva lancar pada tahun 2015 yaitu Rp. 283.354 belum dapat menyediakan dana untuk menutupi kewajiban jangka pendek yaitu sebesar Rp.379.305. Hal ini dikarenakan oleh hutang lancar yang mengalami kenaikan dan aktiva lancar mengalami penurunan pada tahun 2015 dibandingkan tahun 2014 atau dengan kata lain hutang lancar lebih besar daripada aktiva lancar. Hasil current ratio yang di dapat belum mencapai standar industri current ratio yang telah ditetapkan yaitu sebesar 2 kali.

$2016=\frac{206 \cdot 172}{233 \cdot 819}=0,88$ kali

Pada tahun 2016 current ratio yang di peroleh sebesar 0,88 kali yang artinya aktiva lancar pada tahun 2016 yaitu Rp. 206.172 belum dapat menyediakan dana untuk menutupi kewajiban jangka pendek yaitu sebesar Rp.233.819. Hal ini dikarenakan hutang lancar lebih besar daripada aktiva lancar. Walaupun hutang lancar pada tahun 2016 telah mengalami penurunan dibandingkan pada tahun 2015, nilai hutang lancar masih lebih besar dari aktiva lancar karena aktiva lancar juga mengalami penurunan nilai. Hasil current ratio yang di dapat belum mencapai standar industri current ratio yang telah ditetapkan yaitu sebesar 2 kali.

$2017=\frac{257.384}{204.503}=1,26$ kali

Pada tahun 2017 current ratio yang di peroleh sebesar 1,26 kali yang artinya aktiva lancar pada tahun 2017 yaitu Rp. 257.384 belum dapat menyediakan dana untuk menutupi kewajiban jangka pendek yaitu sebesar Rp.204.503. Pada kenyataannya nilai aktiva lebih besar di bandingkan dengan nilai utang lancarnya, walaupun nilai aktiva lancar yang di dapat pada tahun 2017 mengalami kenaikan dan utang lancar mengalami penurunan dibandingkan tahun 2016 tetapi hasil current ratio yang di dapat belum mencapai standar industri current ratio yang telah ditetapkan yaitu sebesar 2 kali.

$2018=\frac{148 \cdot 387}{288.173}=0,51$ kali

Pada tahun 2018 current ratio yang di peroleh sebesar 0,51 kali yang artinya aktiva lancar pada tahun 2018 yaitu Rp. 288.173 belum dapat menyediakan dana untuk menutupi kewajiban jangka pendek yaitu sebesar Rp.233.819. Hal ini dikarenakan hutang lancar lebih besar daripada aktiva lancar. Nilai aktiva lancar yang diperoleh mengalami penurunan dan nilai hutang lancar mengalami kenaikan pada tahun 2018 dibandingkan pada tahun 2017. Hasil current ratio yang di dapat belum mencapai standar industri current ratio 
yang telah ditetapkan yaitu sebesar 2 kali.

Tabel Hasil Perhitungan Current Ratio

\begin{tabular}{|c|c|c|}
\hline Tahun & $\begin{array}{c}\text { Current } \\
\text { Ratio }\end{array}$ & $\begin{array}{l}\text { Standar } \\
\text { Industri }\end{array}$ \\
\hline 2014 & $1,51 \mathrm{kali}$ & \multirow{5}{*}{2 kali } \\
\hline 2015 & 0,75 kali & \\
\hline 2016 & 0,88 kali & \\
\hline 2017 & $1,26 \mathrm{kali}$ & \\
\hline 2018 & 0,51 kali & \\
\hline
\end{tabular}

Jika rata-rata industri untuk current ratio adalah 2 (dua) kali, maka pada tahun 2014-2018 berada dalam kondisi yang kurang baik dikarenakan semua hasil perhitungan current ratio pada tahun 2014-2018 berada dibawah rata-rata industri.

\section{Quick Ratio}

Quick ratio menunjukkan kemampuan perusahaan dalam memenuhi atau membayar kewajiban atau utang lancar dengan aktiva lancar tanpa memperhitungkan nilai persediaan (inventory).

Quick Ratio $=\frac{\text { Current Assets }- \text { Inventory }}{\text { Current liabilities }}$

$2014=\frac{374.881-36.928}{247.862}=1,36$ kali

Pada tahun 2014 quick ratio yang di peroleh sebesar 1,36 kali yang artinya aktiva lancar tanpa persediaan pada tahun 2014 yaitu Rp. 337.953 belum dapat menyediakan dana untuk menutupi kewajiban jangka pendek yaitu sebesar Rp.233.819. Hal ini dikarenakan hutang lancar lebih besar daripada aktiva lancar. walaupun pada kenyataannya nilai aktiva tanpa persediaan lebih besar di bandingkan dengan nilai utang lancarnya, tetapi hasil quick ratio yang di dapat belum mencapai standar industri quick ratio yang telah ditetapkan yaitu sebesar 1,5 kali.

$2015=\frac{283 \cdot 354-16 \cdot 700}{379 \cdot 305}=0,64$ kali

Pada tahun 2015 quick ratio yang di peroleh sebesar 0,64 kali yang artinya aktiva lancar tanpa persediaan pada tahun 2015 yaitu Rp. 266.654 belum dapat menyediakan dana untuk menutupi kewajiban jangka pendek yaitu sebesar Rp.379.305. Hal ini dikarenakan oleh hutang lancar yang mengalami kenaikan dan aktiva lancar tanpa persediaan mengalami penurunan pada tahun 2015 dibandingkan tahun 2014 atau dengan kata lain hutang lancar lebih besar daripada aktiva lancar tanpa persediaan. Hasil quick ratio yang di dapat belum mencapai standar industri quick ratio yang telah ditetapkan yaitu sebesar 1,5 kali.

$2016=\frac{206 \cdot 172-15 \cdot 866}{233 \cdot 819}=0,81$ kali

Pada tahun 2016 quick ratio yang di peroleh sebesar 0,81 kali yang artinya aktiva lancar tanpa persediaan pada tahun 2016 yaitu Rp. 190.306 belum dapat menyediakan dana untuk menutupi kewajiban jangka pendek yaitu sebesar Rp.233.819. Hal ini dikarenakan hutang lancar lebih besar daripada aktiva lancar. Walaupun hutang lancar pada tahun 2016 telah mengalami penurunan dibandingkan pada tahun 2015, nilai hutang lancar masih lebih besar dari aktiva lancar tanpa persediaan karena aktiva lancar tanpa persediaan juga mengalami penurunan nilai. Hasil quick ratio yang di dapat belum mencapai standar industri quick ratio yang telah ditetapkan yaitu sebesar 1,5 kali.

$2017=\frac{257.384-50.089}{204.503}=1,01$ kali 
Pada tahun 2017 quick ratio yang di peroleh sebesar 1,01 kali yang artinya aktiva lancar tanpa persediaan pada tahun 2017 yaitu Rp. 207.295 belum dapat menyediakan dana untuk menutupi kewajiban jangka pendek yaitu sebesar Rp.204.503. Pada kenyataannya nilai aktiva tanpa persediaan lebih besar di bandingkan dengan nilai utang lancarnya, walaupun nilai aktiva lancar tanpa persediaan yang di dapat pada tahun 2017 mengalami kenaikan dan utang lancar mengalami penurunan dibandingkan tahun 2016 tetapi hasil quick ratio yang di dapat belum mencapai standar industri quick ratio yang telah ditetapkan yaitu sebesar 1,5 kali.

$2018=\underline{148 \cdot 387-13 \cdot 726}=0,47$ kali

$$
288.173
$$

Pada tahun 2018 quick ratio yang di peroleh sebesar 0,47 kali yang artinya aktiva lancar tanpa persediaan pada tahun 2018 yaitu Rp. 134.661 belum dapat menyediakan dana untuk menutupi kewajiban jangka pendek yaitu sebesar Rp.233.819. Hal ini dikarenakan hutang lancar lebih besar daripada aktiva lancar tanpa persediaan. Nilai aktiva lancar tanpa persediaan yang diperoleh mengalami penurunan dan nilai hutang lancar mengalami kenaikan pada tahun 2018 dibandingkan pada tahun 2017. Hasil quick ratio yang di dapat belum mencapai standar industri quick ratio yang telah ditetapkan yaitu sebesar 1,5 kali.

\section{Tabel Hasil Perhitungan Quick Ratio}

\begin{tabular}{|c|c|c|}
\hline Tahun & $\begin{array}{l}\text { Quick } \\
\text { Ratio }\end{array}$ & $\begin{array}{l}\text { Standar } \\
\text { Industri }\end{array}$ \\
\hline 2014 & $1,36 \mathrm{kali}$ & \multirow{5}{*}{$1,5 \mathrm{kali}$} \\
\hline 2015 & 0,64 kali & \\
\hline 2016 & 0,81 kali & \\
\hline 2017 & $1,01 \mathrm{kali}$ & \\
\hline 2018 & 0,47 kali & \\
\hline
\end{tabular}

Jika rata-rata industri untuk Quick Ratio adalah 1,5 kali, maka keadaan perusahaan kurang baik dari tahun 2014-2018 walaupun mengalami naik turun hasil perhitungan rasio nya. Hal ini menyebabkan perusahaan harus menjual persediaannya untuk melunasi pembayaran utang lancar, padahal menjual persediaan untuk harga yang normal relatif sulit, kecuali perusahaan menjual di bawah harga pasar yang tentunya bagi perusahaan jelas menambah kerugian.

\section{Rasio Solvabilitas \\ a. Debt to Assets Ratio (DAR)}

Debt to Assets Ratio digunakan untuk mengukur perbandingan antara total utang dengan total aktiva. Dengan kata lain, seberapa besar aktiva perusahaan dibiayai oleh utang atau seberapa besar utang perusahaan berpengaruh terhadap pengelolaan aktiva.

Debt to Assets Ratio $=\frac{\text { Total Debt }}{\text { Total Assets }}$

$2014=\frac{1.587 .371}{3.187 .520}=0,49$ atau $49 \%$

Pada tahun 2014 debt to assets ratio yang di peroleh sebesar $49 \%$ yang artinya $49 \%$ dari jumlah total aset Rp. 3.187.520 dibiayai oleh hutang sebesar Rp 1.587.371 yang nilainya hampir separuh dari total aset. Hasil debt to assets ratio yang di dapat melebihi standar industri debt to assets ratio yang telah ditetapkan yaitu sebesar 35\% dan dinilai kurang baik.

$2015=\frac{1.679 .809}{3.201 .105}=0,52$ atau $52 \%$

Pada tahun 2015 debt to assets ratio yang di peroleh sebesar $52 \%$ yang artinya $52 \%$ dari jumlah total aset $\mathrm{Rp}$. 3.201.105 dibiayai oleh hutang 
sebesar Rp 1.679.809 yang nilainya lebih dari separuh dari total aset. Walaupun nilai total hutang dan nilai total aset pada tahun 2015 mengalami kenaikan dibandingkan tahun 2014, hasil debt to assets ratio yang di dapat melebihi standar industri debt to assets ratio yang telah ditetapkan yaitu sebesar 35\% dan dinilai kurang baik.

$2016=\frac{1.683 \cdot 125}{3.232 \cdot 644}=0,52$ atau $52 \%$

Pada tahun 2016 debt to assets ratio yang di peroleh sebesar $52 \%$ yang artinya $52 \%$ dari jumlah total aset $\mathrm{Rp}$. 3.232.644 dibiayai oleh hutang sebesar $\mathrm{Rp} 1.683 .125$ yang nilainya lebih dari separuh dari total aset. Walaupun nilai total hutang dan nilai total aset pada tahun 2016 mengalami kenaikan dibandingkan tahun 2015, hasil debt to assets ratio yang di dapat melebihi standar industri debt to assets ratio yang telah ditetapkan yaitu sebesar 35\% dan dinilai kurang baik.

$2017=\frac{2.294 .060}{4.964 .076}=0,46$ atau $46 \%$

Pada tahun 2017 debt to assets ratio yang di peroleh sebesar $46 \%$ yang artinya $46 \%$ dari jumlah total aset $R p$. 2.294.060 dibiayai oleh hutang sebesar $\mathrm{Rp}$ 4.964.076 yang nilainya hampir separuh dari total aset. Walaupun nilai total hutang dan nilai total aset pada tahun 2017 mengalami kenaikan dibandingkan tahun 2016, hasil debt to assets ratio yang di dapat melebihi standar industri debt to assets ratio yang telah ditetapkan yaitu sebesar 35\% dan dinilai kurang baik.

$2018=\frac{2 \cdot 402 \cdot 516}{3 \cdot 547 \cdot 023}=0,67$ atau $67 \%$

Pada tahun 2018 debt to assets ratio yang di peroleh sebesar $67 \%$ yang artinya $67 \%$ dari jumlah total aset $\mathrm{Rp}$. 2.402.516 dibiayai oleh hutang sebesar $\mathrm{Rp} 3.547 .023$ yang nilainya lebih dari separuh dari total aset. Walaupun nilai total hutang mengalami kenaikan dan nilai total aset mengalami penurunan pada tahun 2016 dibandingkan tahun 2015, hasil debt to assets ratio yang di dapat melebihi standar industri debt to assets ratio yang telah ditetapkan yaitu sebesar $35 \%$ dan dinilai kurang baik.

\section{Tabel Hasil Perhitungan Debt To Assets Ratio}

\begin{tabular}{|c|c|c|}
\hline Tahun & DAR & Standar Industri \\
\hline 2014 & $49 \%$ & \\
\hline 2015 & $52 \%$ & \\
\hline 2016 & $52 \%$ & \multirow{2}{*}{$35 \%$} \\
\hline 2017 & $46 \%$ & \\
\hline 2018 & $67 \%$ & \\
\hline
\end{tabular}

Dari hasil perhitungan menunjukkan bahwa pada tahun 20142018 rasio yang diperoleh tinggi atau di atas rata-rata industri yang artinya pendanaan dengan utang semakin banyak, maka semakin sulit bagi perusahaan untuk memperoleh tambahan pinjaman dikhawatirkan perusahaan tidak mampu menutupi utang-utangnya dengan aktiva yang dimiliki.

\section{Debt to Equity Ratio (DER)}

Debt to equity ratio digunakan untuk mengetahui jumlah dana yang disediakan peminjam (kreditor) dengan pemilik perusahaan. Dengan kata lain, DER berfungsi untuk mengetahui setiap rupiah modal sendiri yang dijadikan untuk jaminan utang.

Debt to equity ratio $=\frac{\text { Total Utang }(\text { Debt })}{\text { Ekuitas }(\text { Equity })}$

$2014=\frac{1.587 \cdot 371}{1.600 \cdot 149}=0,99$ atau $99 \%$

Pada tahun 2014 debt to equity ratio yang di peroleh sebesar 99\% yang artinya $99 \%$ dari jumlah total ekuitas 
Rp. 1.600.149 dibiayai oleh kreditor sebesar Rp 1.587.371 yang nilainya hampir seluruh dari total aset. Hasil debt to equity ratio yang di dapat melebihi standar industri debt to equity ratio yang telah ditetapkan yaitu sebesar $90 \%$ dan dinilai kurang baik.

$2015=\frac{1.679 .809}{1.503 .296}=1,11$ atau $111 \%$

Pada tahun 2015 debt to equity ratio yang di peroleh sebesar $111 \%$ yang artinya $111 \%$ dari jumlah total ekuitas Rp. 1.503.296 dibiayai oleh kreditor sebesar $\mathrm{Rp} 1.679 .809$ yang nilainya lebih dari seluruh total aset. Pada tahun 2015 total ekuitas mengalami penurunan dan total hutang mengalami kenaikan dibandingkan tahun 2014. Hasil debt to equity ratio yang di dapat melebihi standar industri debt to equity ratio yang telah ditetapkan yaitu sebesar $90 \%$ dan dinilai kurang baik.

$$
2016=\frac{1.683 .125}{1.549 .519}=1,08 \text { atau } 108 \%
$$

Pada tahun 2016 debt to equity ratio yang di peroleh sebesar $108 \%$ yang artinya $108 \%$ dari jumlah total ekuitas Rp. 1.549 .519 dibiayai oleh kreditor sebesar $\mathrm{Rp} 1.683 .519$ yang nilainya lebih dari seluruh total aset. Pada tahun 2016 total ekuitas dan total hutang mengalami kenaikan dibandingkan tahun 2015. Hasil debt to equity ratio yang di dapat melebihi standar industri debt to equity ratio yang telah ditetapkan yaitu sebesar $90 \%$ dan dinilai kurang baik.

$$
2017=\frac{2.294 .060}{2.670 .016}=0,86 \text { atau } 86 \%
$$

Pada tahun 2017 debt to equity ratio yang di peroleh sebesar $86 \%$ yang artinya $86 \%$ dari jumlah total ekuitas Rp. 2.670.016 dibiayai oleh kreditor sebesar Rp 2.294.060 yang nilainya hampir seluruh total aset. Pada tahun 2017 total ekuitas dan total hutang mengalami kenaikan dibandingkan tahun 2016 . Hasil debt to equity ratio yang di dapat lurang dari standar industri debt to equity ratio yang telah ditetapkan yaitu sebesar $90 \%$ dan dinilai baik.

$2018=\frac{2.402 .516}{1.144 .507}=2,09$ atau $209 \%$

Pada tahun 2018 debt to equity ratio yang di peroleh sebesar $209 \%$ yang artinya $209 \%$ dari jumlah total ekuitas Rp. 1.144.507 dibiayai oleh kreditor sebesar Rp 2.402.516 yang nilainya lebih dari seluruh total aset. Pada tahun 2018 total ekuitas mengalami penurunan dan total hutang mengalami kenaikan dibandingkan tahun 2015. Hasil debt to equity ratio yang di dapat melebihi standar industri debt to equity ratio yang telah ditetapkan yaitu sebesar $90 \%$ dan dinilai kurang baik.

Tabel Hasil Perhitungan Debt To Equity Ratio

\begin{tabular}{|c|c|c|}
\hline Tahun & DER & Standar Industri \\
\hline 2014 & $99 \%$ & \\
\hline 2015 & $111 \%$ & \\
\hline 2016 & $108 \%$ & \multirow{2}{*}{$90 \%$} \\
\hline 2017 & $86 \%$ & \\
\hline 2018 & $209 \%$ & \\
\hline
\end{tabular}

Dari hasil perhitungan diatas menunjukan bahwa pada tahun 20142018 rasio yang diperoleh secara keseluruhan adalah tinggi diatas ratarata industri (90\%), perusahaan dianggap kurang baik, kecuali pada tahun 2017 yang memperoleh rasio sebesar 86 \%. Bagi kreditor, semakin besar rasio ini akan semakin tidak menguntungkan karena akan semakin besar resiko yang ditanggung atas kegagalan yang mungkin terjadi di perusahaan. 
3. Rasio Profitabilitas

a. Net Profit Margin (NPM)

Net profit margin (NPM) merupakan ukuran keuntungan dengan membandingkan antara laba setelah bunga dan pajak dibandingkan dengan penjualan atau dengan kata lain menunjukkan pendapatan bersih perusahaan atas penjualan.

$\mathrm{NPM}=\frac{\text { Earning After Interest and Tax }}{\text { Sales }}$

$2014=\frac{98.421}{405.328} \times 100 \%=24.28 \%$

Pada tahun 2014 net profit margin yang di peroleh sebesar $24,28 \%$ yang artinya $24,28 \%$ dari jumlah penjualan Rp. 405.328 diperoleh laba bersih sebesar Rp. 98.421. Hasil net profit margin yang di dapat melebihi standar industri net profit margin yang telah ditetapkan yaitu sebesar $20 \%$ dan dinilai baik.

$2015=\frac{95.845}{427.623} \times 100 \%=22.41 \%$

Pada tahun 2015 net profit margin yang di peroleh sebesar $22,41 \%$ yang artinya $22,41 \%$ dari jumlah penjualan Rp. 427.623 diperoleh laba bersih sebesar Rp. 95.845. Walaupun laba bersih yang dicapai pada tahun 2015 mengalami penurunan dan penjualan meningkat dibandingkan pada tahun 2014. Hasil net profit margin yang di dapat melebihi standar industri net profit margin yang telah ditetapkan yaitu sebesar $20 \%$ dan dinilai baik.

$2016=\frac{50.900}{462.840} \times 100 \%=10.99 \%$

Pada tahun 2016 net profit margin yang di peroleh sebesar 10,99\% yang artinya $10,99 \%$ dari jumlah penjualan Rp. 462.840 diperoleh laba bersih sebesar Rp. 50.900. Laba bersih yang dicapai pada tahun 2016 mengalami penurunan dan penjualan meningkat dibandingkan pada tahun 2015. Hasil net profit margin yang di dapat kurang dari standar industri net profit margin yang telah ditetapkan yaitu sebesar $20 \%$ dan kurang baik.

$2017=\frac{31.816}{491.605} \times 100 \%=6.47 \%$

Pada tahun 2017 net profit margin yang di peroleh sebesar $6,47 \%$ yang artinya $6,47 \%$ dari jumlah penjualan Rp. 491.605 diperoleh laba bersih sebesar Rp. 31.816. Laba bersih yang dicapai pada tahun 2017 mengalami penurunan dan penjualan meningkat dibandingkan pada tahun 2016. Hasil net profit margin yang di dapat kurang dari standar industri net profit margin yang telah ditetapkan yaitu sebesar $20 \%$ dan kurang baik.

$$
2018=\frac{-1.547 .604}{544.884} \times 100 \%=-284.02 \%
$$

Pada tahun 2018 net profit margin yang di peroleh sebesar $-284,02 \%$ yang artinya $-284,02 \%$ dari jumlah penjualan Rp. 544.884 diperoleh rugi bersih sebesar -Rp. 1.547.604 . Rugi bersih yang dicapai pada tahun 2018 mengalami penurunan dan penjualan meningkat dibandingkan pada tahun 2017. Hasil net profit margin yang di dapat kurang dari standar industri net profit margin yang telah ditetapkan yaitu sebesar $20 \%$ dan kurang baik.

Tabel Hasil Perhitungan Net Profit Margin

\begin{tabular}{|c|c|c|}
\hline Tahun & NPM & Standar Industri \\
\hline 2014 & $24,28 \%$ & \\
\hline 2015 & $22,41 \%$ & \\
\hline 2016 & $10,99 \%$ & \multirow{2}{*}{$20 \%$} \\
\hline 2017 & $6,47 \%$ & \\
\hline 2018 & $-284,02 \%$ & \\
\hline
\end{tabular}

Pada tahun 2014 dan 2015 dikatakan baik karena hasil perhitungan NPM berada di atas ratarata industri yaitu sebesar $24,24 \%$ dan 
22,41\%. Pada tahun 2016 dan 2017 dikatakan tidak baik dikarenakan hasil perhitungan NPM berada dibawah rata-rata standar industri yaitu sebesar $10,99 \%$ dan $6,47 \%$. Sedangkan pada tahun 2018 mengalami penurunan yang sangat signifikan yaitu menjadi sebesar $-284,02 \%$. Hal ini dapat berarti bahwa harga-harga barang-barang perusahaan ini relatif rendah atau biaya-biaya relatif tinggi atau keduanya.

\section{b. Return on Assets Investment (ROI)}

Return on Assets Investment (ROI) menunjukkan produktivitas dari seluruh dana perusahaan, baik modal pinjaman maupun modal sendiri.

$\mathrm{ROI}=\frac{\text { Earning After Interest } \text { and } \text { Tax }}{\text { Total Assets }}$

$$
2014=\frac{98.421}{3.187 .520}=0.031 \text { atau } 3.1 \%
$$

Pada tahun 2014 return on investment yang di peroleh sebesar 3,1\% yang artinya $3,1 \%$ dari jumlah total aset $R p$. 3.187.520 diperoleh laba bersih sebesar Rp. 98.421. Hasil return on investment yang di dapat kurang dari standar industri return on investment yang telah ditetapkan yaitu sebesar $30 \%$ dan dinilai kurang baik.

$$
2015=\frac{95.845}{3.201 .105}=0.029 \text { atau } 2.9 \%
$$

Pada tahun 2015 return on investment yang di peroleh sebesar 2,9\% yang artinya $2,9 \%$ dari total aset $\mathrm{Rp}$. 3.201.105 diperoleh laba bersih sebesar Rp. 95.845. Walaupun laba bersih yang dicapai pada tahun 2015 mengalami penurunan dan total aset meningkat dibandingkan pada tahun 2014. Hasil return on investment yang di dapat kurang dari standar industri return on investment yang telah ditetapkan yaitu sebesar 30\% dan dinilai kurang baik.

$$
2016=\frac{50.900}{3.232 .644}=0.015 \text { atau } 1.5 \%
$$

Pada tahun 2016 return on investment yang di peroleh sebesar $1,5 \%$ yang artinya $1,5 \%$ dari total aset $\mathrm{Rp}$. 3.232.644 diperoleh laba bersih sebesar Rp. 50.900. Walaupun laba bersih yang dicapai pada tahun 2016 mengalami penurunan dan total aset meningkat dibandingkan pada tahun 2015. Hasil return on investment yang di dapat kurang dari standar industri return on investment yang telah ditetapkan yaitu sebesar $30 \%$ dan dinilai kurang baik.

$$
2017=\frac{31.816}{4.964 .076}=0.006 \text { atau } 0.6 \%
$$

Pada tahun 2017 return on investment yang di peroleh sebesar $0,6 \%$ yang artinya $0,6 \%$ dari total aset $\mathrm{Rp}$. 4.964.076 diperoleh laba bersih sebesar Rp. 31.816. Walaupun laba bersih yang dicapai pada tahun 2017 mengalami penurunan dan total aset meningkat dibandingkan pada tahun 2016. Hasil return on investment yang di dapat kurang dari standar industri return on investment yang telah ditetapkan yaitu sebesar $30 \%$ dan dinilai kurang baik.

$$
2018=\frac{-1.547 .604}{3.547 .023}=-0.436 \text { atau }-43.63 \%
$$

Pada tahun 2018 return on investment yang di peroleh sebesar $-43,63 \%$ yang artinya $-43,63 \%$ dari total aset $R p$. 3.547.023 diperoleh rugi bersih sebesar -Rp. 1.547.604. Rugi bersih yang dicapai pada tahun 2018 mengalami kenaikan dan total aset menurun dibandingkan pada tahun 2017. Hasil return on investment yang di dapat kurang dari standar industri return on investment yang telah 
ditetapkan yaitu sebesar 30\% dan dinilai kurang baik.

Tabel Hasil Perhitungan

Return On Investment

\begin{tabular}{|c|c|c|}
\hline Tahun & ROI & Standar Industri \\
\hline 2014 & $3,1 \%$ & \\
\hline 2015 & $2,9 \%$ & \\
\hline 2016 & $1,5 \%$ & \multirow{2}{*}{$30 \%$} \\
\hline 2017 & $0,6 \%$ & \\
\hline 2018 & $-43,63 \%$ & \\
\hline
\end{tabular}

Pada tahun 2014-2018 hasil perhitungan ROI menunjukkan bahwa tingkat pengembalian investasi yang diperoleh pada tahun 2014 sebesar 3,1 \%, tahun 2015 mengalami penurunan sebesar $0,2 \%$ menjadi $2,9 \%$, mengalami penurunan kembali pada tahun 2016 menjadi $1,5 \%$, dan tahun 2017 sebesar $0,6 \%$ sangat rendah dari rata-rata industri yaitu sebesar 30 \%. Rendahnya rasio ini disebabkan rendahnya margin laba karena rendahnya perputaran aktiva. Pada tahun 2018 mengalami penurunan menjadi $-43,63 \%$ yaitu sangat jauh dari rata-rata industri yang menunjukkan bahwa ketidakmampuan manajemen untuk memperoleh ROI.

\section{c. Earning Per Share of Common Stock (EPS)}

Rasio laba per lembar saham mengukur keberhasilan manajemen dalam mencapai keuntungan bagi pemegang saham.

$$
\begin{aligned}
& \mathrm{EPS}=\frac{\text { Laba saham biasa }}{\text { Saham biasa yang beredar }} \\
& 2014=\frac{1.617 .000 .000}{6.000 .000}=\mathrm{Rp} .296,50
\end{aligned}
$$$$
2015=\frac{1.534 .000 .000}{6.000 .000}=\operatorname{Rp} .255,66
$$

$$
\begin{aligned}
& 2016=\frac{878.000 .000}{6.000 .000}=\mathrm{Rp} .146,33 \\
& 2017=\frac{512.000 .000}{6.000 .000}=\mathrm{Rp} .85,33 \\
& 2018=\frac{-25.599 .000 .000}{6.000 .000}=-\mathrm{Rp} .4 .266,50 \\
& \quad \text { Tabel Hasil Perhitungan } \\
& \text { Earning Per Share Of Common Stock }
\end{aligned}
$$

\begin{tabular}{|c|c|}
\hline Tahun & EPS \\
\hline 2014 & $\operatorname{Rp} 296,50$ \\
\hline 2015 & $\operatorname{Rp} 255,66$ \\
\hline 2016 & $\operatorname{Rp~} 146,33$ \\
\hline 2017 & $\operatorname{Rp~} 85,33$ \\
\hline 2018 & $-\operatorname{Rp} 4.266,50$ \\
\hline
\end{tabular}

Dari hasil perhitungan diatas dapat dikatakan bahwa selama tahun 2014 hingga 2017 Earning per share of common stock selalu mengalami penurunan terlihat bahwa kesejahteraan pemegang saham menurun, sehubungan dengan menurunnya laba per lembar saham yang dihasilkan perusahaan. Pada tahun 2014 memperoleh Rp 296,50 , tahun 2015 mengalami penurunan dari tahun 2012 sebesar Rp 40,84 menjadi Rp 255,66 . Tahun 2016 mengalami penurunan kembali dari tahun 2015 sebesar Rp 109,33 menjadi Rp 146,33. Tahun 2017 mengalami penurunan dari tahun 2016 sebesar Rp 61 menjadi 85,33. Sedangkan pada tahun 2018 mengalami penurunan yang signifikan yaitu menjadi sebesar Rp 4.266,50.

\section{E. PEMBAHASAN}

Berikut disajikan hasil perhitungan rasio-rasio PT. Goldman Costco Tbk pada tahun 2014-2018 dalam bentuk tabel sebagai berikut: 
Tabel Hasil Perhitungan Rasio Tahun 2014-2018

\begin{tabular}{|l|c|c|c|c|c|c|c|}
\hline \multirow{2}{*}{ Tahun } & \multicolumn{2}{|c|}{ Likuiditas } & \multicolumn{2}{|c|}{ Solvabilitas } & \multicolumn{3}{|c|}{ Profitabilitas } \\
\cline { 2 - 8 } & $\begin{array}{c}\text { Current } \\
\text { ratio }\end{array}$ & $\begin{array}{c}\text { Quick } \\
\text { ratio }\end{array}$ & DAR & DER & NPM & ROI & EPS \\
\hline 2014 & $1,51 \mathrm{kali}$ & $1,36 \mathrm{kali}$ & $49 \%$ & $99 \%$ & $24,28 \%$ & $3,1 \%$ & $\mathrm{Rp} \mathrm{296,50}$ \\
\hline 2015 & $0,75 \mathrm{kali}$ & $0,64 \mathrm{kali}$ & $52 \%$ & $111 \%$ & $22,41 \%$ & $2,9 \%$ & $\mathrm{Rp} \mathrm{255,66}$ \\
\hline 2016 & $0,88 \mathrm{kali}$ & $0,81 \mathrm{kali}$ & $52 \%$ & $108 \%$ & $10,99 \%$ & $1,5 \%$ & $\mathrm{Rp} \mathrm{146,33}$ \\
\hline 2017 & $1,26 \mathrm{kali}$ & $1,01 \mathrm{kali}$ & $46 \%$ & $86 \%$ & $6,47 \%$ & $0,6 \%$ & $\mathrm{Rp} \mathrm{85,33}$ \\
\hline 2018 & $0,51 \mathrm{kali}$ & $0,47 \mathrm{kali}$ & $67 \%$ & $209 \%$ & $-284,02 \%$ & $-43,63 \%$ & $-\mathrm{Rp} 4.266,50$ \\
\hline $\begin{array}{l}\text { Standar } \\
\text { industri }\end{array}$ & $2 \mathrm{kali}$ & $1,5 \mathrm{kali}$ & $35 \%$ & $90 \%$ & $20 \%$ & $30 \%$ & \\
\hline
\end{tabular}

1. Rasio likuiditas PT. Goldman Costco Tbk, berdasarkan hasil penelitian dengan menggunakan current ratio dan quick ratio dapat dilihat bahwa perusahaan tergolong perusahaan yang tidak likuid (il-likuid) karena kurang mampu untuk membayar utang dengan aktiva lancar yang dimilikinya, maka keadaan perusahaan dari tahun 2014-2018 dinilai tidak baik karena hasilnya dibawah nilai rata-rata standar industri.

2. Rasio solvabilitas PT. Goldman Costco Tbk, berdasarkan hasil penelitian dengan menggunakan debt to assets ratio dan debt to equity ratio menunjukkan kondisi perusahaan dinilai kurang baik karena berada diatas rata-rata industri kecuali pada perhitungan debt to equity ratio tahun 2017 yang berada di bawah standar industri yaitu sebesar $86 \%$. Bagi para kreditor, semakin besar rasio ini akan semakin tidak menguntungkan karena akan semakin besar resiko yang ditanggung atas kegagalan yang mungkin terjadi di perusahaan. Maka perusahaan dapat dikatakan lebih dari separuh pendanaan perusahaannya dibiayai oleh hutang.
3. Rasio profitabilitas PT. Goldman Costco Tbk, berdasarkan hasil penelitian dengan menggunakan net profit margin, return on investment dan earning per share of common stock. Pada net profit margin ada 3 tahun yang dapat dikatakan dalam kondisi baik yaitu tahun 2014 dan 2015 yang masing-masing memperoleh nilai rasio $24,28 \%$ dan $22,41 \%$. Tahun 2016 dan tahun 2017 dan terutama tahun 2018 mengalami penurunan yang sangat signifikan dan dikatakan kurang baik dikarenakan berada dibawah standar industri yaitu masingmasing nilai rasio $10,99 \%, 6,47 \%$ dan $-282,02 \%$. Pada return on investment tahun 2014-2018 perusahaan dikatakan tidak baik karena berada dibawah rata-rata industri terutama pada tahun 2018 dibawah rata-rata industri yaitu sebesar $-43,63 \%$. Pada earning per share of common stock pada tahun 2014 hingga 2018 selalu mengalami penurunan yang cukup besar terlihat bahwa kesejahteraan pemegang saham menurun, artinya kemampuan perusahaan untuk mencari keuntungan dikatakan gagal. 


\section{F. KESIMPULAN DAN SARAN}

1. Kesimpulan

Berdasarkan analisis penilaian kinerja keuangan menggunakan rasio likuiditas, rasio solvabilitas dan rasio profitabilitas pada PT. Goldman Costco Tbk selama 5 (lima) tahun yaitu tahun 2014-2018 maka penulis menyimpulkan kinerja keuangan perusahaan tersebut adalah sebagai berikut:

1. Tingkat rasio likuiditas pada PT. Goldman Costco Tbk

a. $\quad$ Current ratio pada tahun 20142018 di nilai kurang baik, karena berada di bawah standar industri. Tahun 2014 current ratio yang diperoleh sebesar 1,51 kali, tahun 2015 sebesar 0,75 kali, tahun 2016 sebesar 0,88 kali, tahun 2017 sebesar 1,26 kali, dan tahun 2018 sebesar 0,51 kali. Sedangkan standar industri current ratio adalah 2 kali. Setelah di analisa dari laporan keuangan di dapat bahwa dari tahun 2014-2018 rata-rata nilai hutang lancar lebih besar dibandingkan dengan aset lancar atau dengan kata lain dapat dikatakan bahwa perusahaan kekurangan modal untuk membayar hutang.

b. $\quad$ Quick ratio pada tahun 20142018 di nilai kurang baik karena berada di bawah standar industri. Tahun 2014 quick ratio yang diperoleh sebesar 1,36 kali, tahun 2015 sebesar 0,64 kali, tahun 2016 sebesar 0,81 kali, tahun 2017 sebesar 1,01 kali, dan tahun 2018 sebesar 0,47 kali. Sedangkan standar industri quick ratio sebesar 1,5 kali. Dilihat dari hasil perhitungan rasio yang di dapat, perusahaan di haruskan menjual persediaannya untuk melunasi pembayaran hutang lancar. Menjual persediaan untuk harga yang normal relatif sulit, perusahaan harus membuat pilihan keputusan untuk menjual persediaan dibawah harga pasar dengan konsekuensinya menanggung tambahan kerugian atau masih menjual persediaan dengan harga yang normal dengan waktu yang cukup lama dalam penjualannya.

2. Tingkat rasio solvabilitas pada PT. Goldman Costco Tbk

a. Debt to assets ratio pada tahun 2014-2018 di nilai kurang baik karena rasio yang diperoleh sangat tinggi atau diatas ratarata industri. Pada tahun 2014 debt to assets ratio yang diperoleh sebesar $49 \%$, tahun 2015 sebesar $52 \%$, tahun 2016 sebesar $52 \%$, tahun 2017 sebesar $46 \%$ dan tahun 2018 sebesar $67 \%$. Sedangkan standar industri debt to assets ratio adalah sebesar $35 \%$. Berdasarkan perolehan rasio yang di dapat tersebut, artinya pendanaan dengan utang di dalam perusahaan semakin banyak. Hal ini akan menyebabkan perusahaan akan mengalami kesulitan untuk memperoleh tambahan pinjaman karena dikhawatirkan perusahaan tidak mampu menutupi utang-utang nya dengan aktiva yang dimiliki. Dilihat dari analisa rata-rata perhitungan rasio di dapat bahwa perusahaan dibiayai hampir separuhnya hutang.

b. Debt to equity ratio pada tahun 2014-2018 di nilai kurang baik karena berada di atas rata-rata 
industri. Pada tahun 2014 debt to equity ratio yang diperoleh sebesar $99 \%$, tahun 2015 sebesar $111 \%$, tahun 2016 sebesar $108 \%$, tahun 2017 sebesar $86 \%$, dan tahun 2018 sebesar $209 \%$. Sedangkan standar industri debt to equity ratio sebesar $90 \%$. Hal ini berarti dana yang disediakan oleh kreditor jumlahnya begitu besar, dengan kata lain modal yang dijadikan untuk jaminan hutang juga harus sebanding besarnya dengan jumlah yang dipinjamkan oleh kreditor. Di lihat dari analisa laporan keuangan dari tahun 2014-2018 rata-rata ekuitas yang dimiliki perusahaan lebih rendah di bandingkan dengan total hutang. Bagi para kreditor, hal ini tidaklah sangat menguntungkan karena akan semakin besar resiko yang ditanggung atas kegagalan yang mungkin terjadi di perusahaan.

3. Tingkat rasio profitabilitas pada PT. Goldman Costco Tbk

a. Net profit margin pada tahun 2014 dan 2015 dikatakan baik karena di atas rata-rata industri. Tetapi, pada tahun 2016-2018 dikatakan tidak baik karena berada di bawah rata-rata industri. Pada tahun 2014 net profit margin yang diperoleh sebesar 24,28\%, tahun 2015 sebesar 22,41\%, tahun 2016 sebesar $10,99 \%$, tahun 2017 sebesar $6,47 \%$ dan tahun 2018 sebesar $-284,02 \%$. Sedangkan standar industri net profit margin adalah sebesar $20 \%$. Dilihat dari analisa laporan keuangan rasio yang di dapat rendah dikarenakan biaya-biaya yang ditanggung oleh perusahaan cukup tinggi terutama pada biaya/beban keuangan setiap tahun terus meningkat.

b. Return on investment pada tahun 2014-2018 di nilai kurang baik karena di bawah rata-rata industri. Pada tahun 2014 return on investment diperoleh sebesar 3,1\%, tahun 2018 sebesar 2,9\%, tahun 2016 sebesar 1,5\%, tahun 2017 sebesar $0,6 \%$ dan tahun 2018 sebesar $-43,63 \%$. Dilihat dari analisa laporan keuangan margin laba perusahaan sangat rendah dikarenakan rendahnya perputaran aset. Hal ini menunjukkan bahwa manajemen perusahaan tidak efektif dalam mengelola keseluruhan operasi perusahaan terutama dalam pengelolaan investasi.

Earning per share of common stock pada tahun 2014-2018 di nilai kurang baik karena selalu mengalami penurunan yang cukup besar setiap tahunnya. Pada tahun 2014 earning per share of common stock yang di peroleh sebesar Rp 296,50, tahun 2018 sebesar Rp 255,66, tahun 2016 sebesar Rp 146,33, tahun 2017 sebesar $\mathrm{Rp} \mathrm{85,33}$ dan tahun 2018 sebesar -Rp 4.266,50. Dari hasil perhitungan rasio tersebut, terlihat bahwa kesejahteraan pemegang saham menurun. Artinya, kemampuan perusahaan untuk mencari keuntungan dapat dikatakan gagal.

\section{Saran}

Berdasarkan permasalahan yang ada pada PT. Goldman Costco Tbk mengenai penilaian kinerja keuangan 
perusahaan, maka penulis mecoba untuk memberikan saran bagi perusahaan untuk permasalahanpermasalahan tersebut, antara lain :

a. Untuk rasio likuiditas perusahaan, baik pada current ratio dan quick ratio sebaiknya perlu meningkatkan jumlah aktiva yang dimiliki agar kegiatan dalam membayar kewajiban dapat berjalan dengan baik. Terutama pada quick ratio sebaiknya pihak perusahaan memilih keputusan yang tepat dan bijak dalam menjual persediaan untuk meninimalisir konsekuensi yang akan terjadi.

b. Untuk rasio solvabilitas, dikarenakan pada rasio ini mengukur sejauh mana aktiva perusahaan dibiayai dengan hutang maka baik pada debt to assets ratio dan debt to equity ratio perusahaan sebaiknya mensiasati kelebihan dan kekurangan pada sumber dana yang dibutuhkan untuk meningkatkan aktiva dengan cara melakukan kombinasi dari masingmasing jumlah sumber dana atau dengan kata lain penggunaan dana yang bersumber dari pinjaman harus di batasi agar tidak terlalu membebani perusahaan pada kewajibannya baik jangka pendek maupun jangka panjang.

c. Untuk rasio profitabilitas, pada net profit margin sebaiknya perusahaan harus lebih efisien dalam mengelola aset yang dimiliki agar dapat menghasilkan laba yang lebih baik. Pada return on investment dan earning per share of common stock, perusahaan perlu melakukan evaluasi pada manajemen perusahaan untuk mencari penyebab ketidakefisienan dan kegagalan dalam pengelolaan operasi perusahaan. Bila diperlukan, mengganti manajemen perusahaan yang lama dengan manajemen yang baru sebaiknya dilakukan demi tercapainya efisiensi kinerja keuangan perusahaan yang lebih baik.

\section{DAFTAR PUSTAKA}

Dwi, Prastowo. 2011. Analisis Laporan Keuangan Konsep dan Aplikasi. Yogyakarta: UPP STIM YKPN.

Fahmi, Irham. 2012. Analisis Kinerja Keuangan. Bandung : Alfabeta.

2016. Analisis Laporan Keuangan. Bandung: Alfabeta.

Handoko, Hani. 2011. Manajemen. Yogyakarta : BPFE-Yogyakarta.

Hery. 2016. Analisis Laporan Keuangan. Jakarta: Grasindo.

Jumingan. 2011. Analisis Laporan Keuangan. Jakarta: Bumi Aksara.

Kasmir. 2017. Analisis Laporan Keuangan. Jakarta: PT. Raja Grafindo Persada

Martani, Dwi. 2012. Akuntansi Keuangan Menengah Berbasis PSAK. Jakarta: Salemba Empat.

Riyanto, Bambang. 2013. Dasar-Dasar Pembelanjaan Perusahaan. Yogyakarta: BPFE.

S. Munawir. 2010. Analisa Laporan Keuangan. Yogyakarta: Liberty.

Sofyan, Syafri, Harahap. 2010. Analisis Kritis Atas Laporan Keuangan. Jakarta: PT. Raja Grafindo Persada.

Sihotang, Sonang. 2013. Analisis Rasio Keuangan Sebagai Alat untuk Menilai Kinerja Keuangan 
PT. International Nickel Corporation, Tbk. Jurnal IImu \& Riset Manajemen Volume 2, Nomor 1, Sekolah Tinggi IImu Ekonomi Indonesia Surabaya.

Sugiyono. 2016. Metode Penelitian Manajemen. Bandung: Alfabeta.

Sugiyono, Arief , Edi Untung. 2016. Panduan Praktis Dasar Analisa Laporan Keuangan. Jakarta: PT. Gramedia.

Suhendro, Dedi. 2017. Analisis Profitabilitas dan Likuiditas untuk
Menilai Kinerja Keuangan Pada $P T$. Siantar Top Tbk. Jurnal Human Falah Volume 4, Nomor 2, AMIK Tunas Bangsa Pematangsiantar Sumatera Utara.

Wibowo, Leonardo. 2013. Analisis Kinerja Keuangan Berdasarkan Rasio Keuangan (Studi Kasus pada PT. Kharisma Prima Abadi Yogyakarta). Jurnal 2013. Program Studi Akuntansi Universitas Dian Nuswantoro Semarang. 